\title{
Analysis of Community Health Workers (SKM) Need Based on Working Time and Workload: A Case Study of Uepai Health Center Konawe Regency
}

\author{
Noniatin $^{1 *}$, Darmawansyah ${ }^{2}$, Aminuddin Syam $^{3}$ \\ ${ }^{1,2}$ Department of Administration and Policy, Faculty of Public Health, Hasanuddin University, Indonesia \\ ${ }^{3}$ Department of Nutrition, Faculty of Public Health, Hasanuddin University, Indonesia
}

\section{*Corresponding Author}

Noniatin

\section{Article History}

Received: 01.06.2020

Accepted: 18.06 .2020

Published: 25.06.2020

\begin{abstract}
This study aims to analyze the Needs of Community Health Workers (SKM) based on work time and workload at the Uepai Health Center, Konawe District. This type of research uses qualitative and quantitative approaches in which data collection is observed using work sampling methods. This research was conducted at the Community Health Centre Uepai Konawe Regency. In this study, the informants in this study were all employees of the Uepai Public Health Center with a public health education background. The informant determination technique used was the inclusion and exclusion criteria so the number of informants in this study was 6 people with a degree in Public Health. In this research, the data analysis used is descriptive analysis. There are two analytical models used, namely interactive model data analysis and descriptive data analysis. The results of research on the amount of work time for community health workers in the Uepai Health Center are 250 days/year or 1450 hours/year. The workload standard is calculated based on the use of direct activity time as the main activity. The number of needs of community health workers in the Uepai Community Health Center based on the results of the WISN method calculation that the number of energy needs is 15 people. From the results of this study, it is suggested that it can be a reference for conducting workload analysis in other units as an evaluation of the availability of human resources owned and carried out periodically in order to get a rational amount of labor needs and monitor productive work activities.
\end{abstract}

Keywords: Working Time, Workload, WISN Method, Community Health Workers.

\section{INTRODUCTION}

Planning for the needs of health workers in Community Health Centre in Permenkes (Minister of Health Regulations) Number 75 of 2014 concerning Community Health Centers, states that the type and number of health workers is calculated based on workload analysis. So far, the planning of health human resources has not yet looked at the level of need for the implementation of service programs that must be carried out, and the existing personnel are still far from the ratio standard [1].

Health human resource policy and program planning is still weak and has not been supported by the availability of adequate information systems related to health human resources, the lack of harmony between the needs and procurement of various types of health human resources, and the lack of equitable quality health human resources [2].

The Community Health Center is one of the technical implementing units of the Health Service that organizes public health efforts and first-level individual health efforts with the main activity being prevention and health promotion activities. Community Health Centre play the role of the spearhead in providing basic health care (primary health care), namely minimal health services to the community in the form of preventive, sustainable, and certainly accessible services for the entire community [1].

Copyright @ 2020: This is an open-access article distributed under the terms of the Creative Commons Attribution license which permits unrestricted use, distribution, and reproduction in any medium for non commercial use (NonCommercial, or CC-BY-NC) provided the original author and source are credited. 
Minister of Health Regulation number 33 of 2015 concerning Guidelines for Preparation of Health Human Resource Planning at the Provincial, Regency / City Level and Hospitals, explains that the planning of Health HR including Community Health personnel in Community Health Centre can be done by calculating workload using the Workload Indicators of Staffing method Need (WISN) [3-5].

This WISN method is a model adopted from WHO that has been developed since 1998. The WISN method has advantages that are easy to use both techniques, comprehensively, and realistic, as well as providing convenience in determining variations in HR needs in various types of health services such as health centers and hospitals [6].

Bachelor of Public Health has superior competence and is usually abbreviated as MIRACLE (Manage, Innovator, Role Model, Apprentice, Communitarian, Leader and Educator). The competency of an SKM makes SKM as one of the health workers needed, especially in Community Health Centre as its role in strengthening promotive and preventive efforts. The Ministry of Health's strategic plan for 2015-2019 mentions the focus of the healthy paradigm is to increase promotive and preventive efforts without ignoring curative and rehabilitative efforts [7].

The number of community health workers (SKM) working at the Community Health Centre working area of the Konaweyang District Health Office consists of 109 civil servants and PHL. Of the 29 Community Health Centre, there are 26 Community Health Centre with a Bachelor of Public Health (SKM) and the remaining 3 Community Health Centre that do not have a Bachelor of Public Health.

Uepai Community Health Centre located in the working area of the Konawe District Health Office. Community Health Centre Uepai has a work area of 18 villages and 1 (one) sub-district. Based on 2019 Profile data, it is known that the Community Health Centre has 6 public health workers (SKM) and 4 non-civil servants. Meanwhile, by looking at the working area of the larger Uepai Community Health Centre, it certainly has a large workload, so that the Uepai Community Health Centre must have an optimal number of public health workers (SKM). In addition, it is not yet known whether all SKM personnel in the Uepai Community Health Center have worked according to the main tasks and functions of the community health workers.

The Konawe District Health Office has so far been in the planning of the needs of health workers, especially community health workers (SKM) at the Community Health Centre, which have not used the workload analysis calculation but are still using the ratio of the number of SKM personnel to the total population and only based on work unit requests. Seeing the importance of the role of community health workers (SKM) in Community Health Centre services, the planning of the number of public health workers (SKM) needs must be in accordance with the workload at the Community Health Centre.

\section{Methods}

This type of research uses qualitative and quantitative approaches, the data collection is done by observing the work sampling method. This research was conducted at the Community Health Centre Uepai Konawe Regency. The informants in this study were all employees of the Uepai Community Health Center with a background in public health education. The informant determination technique used is the inclusion and exclusion criteria so the number of informants in this study were 6 people with a degree in Public Health.

This research uses primary data and secondary data. Primary data obtained from interviews and observations for qualitative data. Secondary data was obtained in writing through a review of important documents related to the workload analysis of community health workers. In this research, the data analysis used is descriptive analysis. Where in this analysis the data obtained from the study are presented as-is then analyzed descriptively to get a picture of the facts that occur. There are two analytical models used, namely interactive model data analysis and descriptive data analysis.

\section{Results}

\section{Calculation of HR Needs using the WISN Method} Analysis of the working time of community health workers at the Uepai Community Health Center

Determine available work time is the time unit used by community health workers (SKM) to work on their main activities for a year. Determining available work time aims to obtain available work time for each category of HR working in the Community Health Centre for a period of one year. 
Table-1: Analysis of Working Time of Community Health Workers in Uepai Community Health Centre

\begin{tabular}{|l|l|l|l|}
\hline \multirow{2}{*}{ NO } & \multirow{2}{*}{ Category } & \multicolumn{2}{|c|}{ Uepai Community Health Centre } \\
\cline { 3 - 4 } & & 6 & Sunday \\
\hline $\mathbf{1}$ & Working days & 5,8 & Hours / Day \\
\hline $\mathbf{2}$ & Working time & 16 & Day/year \\
\hline $\mathbf{3}$ & Leave (Annual, Permit, External Service) & 21 & Day/year \\
\hline $\mathbf{4}$ & National / Regional holidays & 6 & Day/year \\
\hline $\mathbf{5}$ & Sick & 19 & Day/year \\
\hline $\mathbf{6}$ & Training / Seminar & 250 & Day/year \\
\hline $\mathbf{7}$ & Working days & 1450 & Hours / Year \\
\hline $\mathbf{8}$ & Working time available & 87.000 & Minute / Year \\
\hline $\mathbf{9}$ & Working Time in Minutes & & \\
\hline
\end{tabular}

Source: Primary Data. 2020

In table 1 the results of the calculation of working time at the Community Health Centre Uepai Konawe Regency are 250 days/year or 1450 hours/year. The results of these calculations are obtained from the reduction in the amount of work done by the health center during the year with the sum of annual leave, permits, external services, national and regional holidays, sickness, and training/seminars.

Based on the results of the interview related to work time as follows;

"yes, 6 working days"

"Weekdays are 6 days"

$$
\text { (RB, PKM Uepai) }
$$

(DI, PKM Uepai)

"I, as a non-civil servant, do not know about leave but the leader gave a policy for non-civil servant who gave birth was given leave as leave for civil servants"

(SA, PKM Uepai)

"According to the application for leave submitted. If annual leave is for 2 weeks, leave is large for 3 months" (DW, PKM Uepai)

"There are 12 days annual leave, maternity leave and leave for important reasons"

(NS, PKM Uepai)

"Yes there is, every year there must be training in all programs in Konawe district" (RB, PKM Uepai)

"If we only wait for training from the DHO, so what program letters come, so we can't determine the level of education and usually also at the provincial level"

(NS, PKM Uepai)

\section{Standard analysis of the workload of community health workers in the Uepai Community Health Center}

The standard workload for a main activity is prepared based on the time needed to complete (average time) and the time available per year owned by each labor category.

Table-2: Setting the Standards of Workload of Public Health Workers simultaneously in Uepai Community Health Centre

\begin{tabular}{|l|l|l|l|l|}
\hline No & Direct Activity & \multicolumn{3}{|c|}{ PKM Uepai } \\
\hline & & NWK & WK & SBK \\
\hline 1 & Develop a work plan & 60 & 87000 & 1450 \\
\hline 2 & Counseling & 80 & 87000 & 1087 \\
\hline 3 & Data Analysis \& Monitoring & 50 & 87000 & 1740 \\
\hline 4 & Recording and reporting & 50 & 87000 & 1740 \\
\hline 5 & Arrange material & 40 & 87000 & 2175 \\
\hline 6 & Supervision and monitoring & 60 & 87000 & 1450 \\
\hline 7 & Other field activities & 70 & 87000 & 1242 \\
\hline
\end{tabular}

Source: Primary Data. 2020

In table 2 it is known that the determination of standard components of the workload of public health workers, in compiling work plans at the Uepai Community Health Centre at 1450 minutes, counseling at 1087 minutes, analysis and monitoring at 1740 , recording and reporting at 1740 minutes, compiling material at 2175 minutes, supervision and monitoring of 1450 minutes and other field activities of 1242 minutes. 
The results of interviews with informants related to workload are as follows:

"I personally have a lot of workload so that my actual duties are neglected and it doesn't go well because there are a lot of additional activities because as a subordinate, I must also be loyal and total to refuse, maybe because I am also responsible and expected to do activities. that'

$$
\text { (RB, PKM Uepai) }
$$

"The workload here is quite high"

$$
\text { (DI, PKM Uepai) }
$$

"In addition to the important role of SKM workloads in adm Community Health Centre, reporting, programs and others we are still actively down and field activities"

$$
\text { (SA, PKM Uepai) }
$$

From the results of the interview, the workload of the Uepai Community Health Center is quite large so that the officers concerned are overwhelmed in completing the tasks they carry.

Analysis of other types of additional activities and the time required (leeway standard) for community health workers in the Uepai Community Health Center

Table-3: Determination of Standards for Supporting Public Health Workers in the Uepai Health Center

\begin{tabular}{|l|l|l|l|l|}
\hline No & Type of Activity & Average time & Total & Supporting Task Standards \\
\cline { 3 - 4 } & & & Community Health Centre \\
\hline 1 & Meetings \& Meetings & 60 Minutes /week & 3120 & 3,6 \\
\hline 2 & Training and Education and seminars & 120 Minutes/month & 1440 & 1,6 \\
\hline 3 & Other Activities & 60 menit/mgg & 3120 & 3,6 \\
\hline & Supporting Task Factors (FTP) in $\%$ & 8,8 \\
\hline Supporting Task Standards (STP) $=(1 /(1-\mathrm{FTP} / 100))$ & 1,09 \\
\hline
\end{tabular}

Source: Primary Data. 2020

Based on the calculation results in table 3, it can be seen that the standard-setting for supporting health workers in the Uepai Health Center is 1.09. The results obtained from the calculation of the average time divided by the available work time of each Community Health Centre multiplied by one hundred. From the results of interviews with informants related to how the SKM staff at the Community Health Centre have worked in accordance with their main tasks or have other additional activities as follows:

"I don't think there is going well because SKM staff themselves still hold multiple positions such as additional activity positions, I personally as SKM concurrently hold several programs such as health promotion and PTB postbindu"

(RB, PKM Uepai)

"Not in accordance with the discipline of science, double the job, many concurrent additional activities" (DI, PKM Uepai)

\begin{tabular}{|c|c|c|c|c|}
\hline Type of Task & Activity & $\begin{array}{l}\text { Achievements } \\
\text { (1 year) }\end{array}$ & SBK & HRH needs \\
\hline 1 & 2 & 3 & 4 & $5=(3) /(4)$ \\
\hline \multirow[t]{7}{*}{ A. Primary Task } & Develop a work plan & 360 & 1450 & 0,24 \\
\hline & Counseling & 720 & 1087 & 0,66 \\
\hline & Data Analysis \& Monitoring & 2600 & 1740 & 1,49 \\
\hline & Recording and reporting & 13980 & 1740 & 8,03 \\
\hline & Arrange material & 3120 & 2175 & 1,43 \\
\hline & Supervision and monitoring & 600 & 1450 & 0,41 \\
\hline & Other field activities & 1440 & 1242 & 1,15 \\
\hline \multicolumn{4}{|c|}{ JKT = Total Needs of Public Health Task Force } & 13,41 \\
\hline B. Supporting Task & Supporting Task Standard & & & 1,09 \\
\hline \multicolumn{3}{|c|}{ Total HRH Needs (Public Health) } & $(\mathrm{JKTxSTP})$ & 14,6 \\
\hline \multicolumn{4}{|c|}{ Rounding up } & 15 \\
\hline
\end{tabular}

Analysis of the total human resource needs of community health workers in the Uepai Community Health Center

Table-4: Simultaneous calculation of HRH Needs of Community Health Workers at the Uepai Health Center

Source: Primary Data. 2020. 
Based on the calculation of the WISN ratio of community health workers at the Uepai Community Health Center in table 4, the current number of workers is smaller than the number of workers needed to carry out the existing workload. This means that the Uepai Community Health Center needs to add more staff than the required 14.6 staff if rounded up to 15 staff from the 10 existing community health workers.

\section{DISCUSSION}

Based on observations and document review related to the determination of working hours in the Konawe district health office working area, the determination of working time is basically, the provisions on working days for civil servants are regulated in Article 3 number 11 Government Regulation Number 53 Year 2010 concerning Discipline of Civil Servants who require civil servants to enter work and obey working hours requirements.

Furthermore, in the elucidation of this article, it is said that what is meant by the obligation to "come to work and obey the provisions of working hours" is that every civil servant is obliged to come, carry out his duties, and go home according to the provisions of working hours and not be in a public place not because of service. If unable to attend, must notify the competent authority. Delay in coming to work and / or leaving early is calculated cumulatively and converted $71 / 2$ (seven and a half) hours is equal to 1 (one) day of absence from work. More specifically, the provisions on working hours for civil servants are also regulated in Presidential Decree No. 68 of 1995 concerning Working Days in Government Institutions.

From the results of the research conducted it can be concluded that the working time used at the Uepai Health Center in Konawe Regency is 6 working days with a total working hours of 5.8 hours, while for leave (annual, permit, external service) at Upeai Health Center 16 Days/year, and effective working days at Uepai Health Center 250 Days/year. As for the results of the calculation of available work time is obtained from the total working days in one year reduced by the number of days of leave, annual leave, education and training, the average absence of work in a year.

The results of observations and document review related to the determination of working hours in the working area of the Konawe District Health Office, the optimum determination of productive working time is around $80 \%$. This parameter is used to assess whether the workload is really high, not just personnel complaints. If the personnel have worked above $80 \%$ of their productive time, we need to consider and pay attention that the unit really needs additional personnel. It is impossible to expect personnel to work maximum, most rationally expect personnel to work at the optimum point [8].

Standard workload is the amount of activity in a health service workload component that can be carried out by a health worker in one year. Calculation of the standard workload of a health service depends on the standard time of service stated in the form of unit time or rate of work.

From the results of research on workload standards based on activities and observations made at the Uepai Health Center have a different magnitude and value for each productive activity carried out by each public health officer. To find out the average time needed to complete the main activities, observations were obtained and strengthened by in- depth interviews with informants. The highest standard workload based on calculations there is activity at the Uepai Community Health Center based on the results of the calculation of the highest standard workload on extension activities. Norms of work time are determined from the results of field observations conducted by researchers using a measuring device which then the researcher draws a time conclusion adjusted to the informant's information.

From the results of interviews with community health workers at the Uepai Community Health Center, they complained that the workload was excessive, so the main tasks and functions that were supposed to be working were not going well due to the large number of additional activities.

The decline in work quality and performance of community health workers due to high workloads will have an impact on productivity in carrying out health programs is a decline in the image of health centers because the results to be achieved will not be maximized resulting in a decrease in the value of health services to the community [9].

The purpose of setting the standard allowance is to obtain the allowance factors for each HR category, including the type of activity and the time needed to complete an activity that is not directly related or influenced by the quality or number of main activities/services. Other types of additional activities such as holding cross-sectoral meetings and meetings, conducting education, training, and seminars, helping other tasks with the Head of the Community Health Centre, and helping to manage the Community Health Centre finances.

Based on the results of interviews that the implementation of training is usually done during office hours so that officers must leave their work which will be delegated authority to other officers in order to help carry out tasks for 
officers who attend the training, this has an impact on the high workload of officers delegated authority so as to reduce productivity basic work that should be completed on time.

Allowance standards related to activities are obtained from the amount of time for indirect productive activities that support the implementation of main activities (direct productive) meetings with superiors or other relevant unit units and education and training.

From the results of interviews with informants related to the main tasks and other additional tasks at the Uepai Community Health Centre from the results of the interview, it can be concluded that the main tasks of the community health workers have not run optimally because there are still many community health workers who hold other positions, on the other hand, there are still many additional activities provided so the main tasks and tasks that should be the main task are neglected because of the many additional tasks so the allocation of time needed to complete them also requires a long time so that a good management process is needed to improve the work productivity of public health workers.

Based on the results of research related to the needs of community health workers at the Uepai Health Center from the calculation of the WISN method that the number of needed personnel is 14.6 staff if rounded up to 15 people compared to the number of public health workers currently there are 10 people, the addition of the number of workers is 5 person.

The results of in-depth interviews related to the analysis of the needs of public health workers in the work area of the Konawe District Health Office so far have used the ratio method which only looks at the comparison of the number of public health graduates with the population, in contrast to the workload analysis that calculates the needs of public health graduates by taking into account the workload component. So it can be said that the calculation of the needs of graduates of public health through workload analysis is more objective than the ratio method. The results of the calculation of workload analysis are very useful as a measurement of the needs of human resources in an organization as a basis in the norm of work completion time, the level of work efficiency, work performance, preparation of employee formation, and improvement of the work procedure system [10].

\section{CONCLUSION}

The need for community health workers in the Uepai Community Health Center based on the results of the WISN method calculation that the total number of staff needs is 15 compared to the current number of public health workers at 10 people, so the addition of the number of workers is 5 people, so the Health Center in Uepai needs to add staff. It is hoped that the results of this study can be a reference for conducting workload analysis in other units as an evaluation of the availability of human resources owned and carried out periodically in order to obtain a rational amount of workforce needs and monitor productive work activities at the Community Health Centre.

\section{REFERENCES}

1. Reviana, L. S. (2018). Analisis Kebutuhan SDM kesehatan Berdasarkan Standar Ketenagaan Minimal Permenkes nomor 75 Tahun 2014 di Puskesmas Kanor Kabupaten Bojonegoro. Sekolah Tinggi Ilmu Kesehatan Bhakti Husada Mulia.

2. Astiena. (2015). Manajemen Sumber Daya Manusia Kesehatan. Padang: Andalas University.

3. Dharmayuda, A. A. N. G., Wulandari, L. L., \& Wirawan, D. N. (2015). Workload analysis of doctors at Community Health Centre using workload indicators of staffing need in denpasar. Public Health and Preventive Medicine Archive, $3(1)$.

4. Permatasari, E. D., \& Pudjirahardjo, W. J. (2015). Weakness of Workload Indicators of Staffing Need in Calculating the Number of Health Workers in Public Health Center. Jurnal Administrasi Kesehatan Indonesia, 3(1), 89-98.

5. Rizcarachmakurnia N. (2017). Analisis Beban Kerja Dan Kebutuhan Tenaga Perawat Di Puskesmas Poncol Kota. Semarang. Jurnal Kesehatan Masyarakat UNDIP, 5(3):15-29

6. Gaspard, J. (2016). Training needs assessment of health care professionals in a developing country: the example of Saint Lucia. BMC Medical Education, 121(4):150-161.

7. Fandi K. (2016). Analisis Beban Kerja Tenaga Kesehatan Masyarakat Bidang Epidemiologi Pada Puskesmas Kota Semarang. Udinus Repository

8. Ilyas, Y. (2013). Perencanaan SDM Rumah Sakit. Depok: Fakultas Kesehatan Masyarakat Universitas Indonesia.

9. Rubbiana, N.I. (2016). Analisis Beban Kerja dan Kebutuhan Tenaga Perawat Pelaksana Dengan Metode wsorkload Indikator Staff Need (WISN) Di Instalasi Rawat Inap Tulip RSUD Kota Bekasi (Tesis). Jakarta : UIN Syarif Hidayatullah.

10. Wulandari. (2017). Analisis Beban Kerja Mental, Fisik Serta Stres Kerja Pada Perawat Secara Ergonomi Di RSUD Dr. Achmad Mochtar Bukittinggi. JOM Fekon, 4(1)31-44. 